Research Article / Araştırma Makalesi

\title{
THE ENERGY CONSUMPTION-FINANCIAL DEVELOPMENT RELATIONSHIP FOR G-7 COUNTRIES FROM PANEL QUANTILE REGRESSION APPROACH
}

\author{
Assoc. Prof. Ŏ̆uz ÖCAL \\ Kayseri University, Faculty of Applied Sciences, Kayseri, Turkey, (oguzocal@kayseri.edu.tr) \\ Asst. Prof. Volkan HAN (D) \\ Nevşehir Hacı Bektaş Veli University, FEAS, Nevşehir, Turkey, (volkanhan@nevsehir.edu.tr)
}

\begin{abstract}
This study focused on examining the relationship among energy prices, financial development, foreign direct investments and economic growth on energy consumption for G-7 countries covered the 1980-2018 data period. We take into energy use as a dependent variable to project countries energy consumption and also financial development is measured by using BankDindex and BondDindex variables, for economic growth GDP per capita, net inflows for foreign direct investment and Brent crude oil price for energy prices. It has been applied the panel quantile regression model which is a new robust econometric method and two models are established. The empirical findings suggest that diverse variables have a clearly heterogeneous effect on energy use. An increase in both energy prices and foreign direct investments increases energy consumption. In Model 1, the effect of financial development on low energy consumption levels is lower, while the effect of the Banking sector is higher in countries with medium and high energy consumption. In Model 2, the Bond sector has a high impact in countries with low energy consumption but is meaningless. It has a positive and significant effect at levels with medium and high energy consumption. The impact of the banking sector on energy consumption is three times greater than the debt sector. In addition, the banking sector has a significant effect on the quantiles of low EC. We found another results for policymakers, to use financial development role in the economic growth process.
\end{abstract}

Keywords: Energy Consumption, Financial Development, Economic Growth, Panel Quantile Regression, G-7 Countries

\section{G-7 ÜLKELERİ İÇIN PANEL KANTIL REGRESYON YAKLAŞIMIYLA ENERJI TÜKETIMMI-FINANSAL GELIŞME İLIŞKISİ}

\section{ÖZET}

Bu çalışma G-7 ülkelerinde 1980-2018 dönemi için enerji fiyatları, finansal gelişme, doğrudan yabancı yatırım ve ekonomik büyümenin enerji tüketimi ilişkini incelemeye odaklanmıştır. İlgili ülkelerin enerji tüketimi değişkeni için enerji kullanımı değişkenini, finansal gelişme için BankDindex ve BondDindex değişkenlerini, ekonomik büyüme için kişi başına hasıla değiş̧kenini, doğrudan yabancı yatırımlar için net girşleri, enerji fiyatları için Brent ham petrol fiyatları ele alınmıştır. Yeni bir güçlü ekonometrik yöntem olan panel kantil regresyon modeli uygulanmıs ve iki model kurulmuştur. Ampirik bulgular, farklı değişkenlerin enerji kullanımı üzerinde açıkça heterojen bir etkiye sahip olduğunu göstermektedir. Hem enerji fiyatlarındaki hem de doğrudan yabancı yatırımlardaki artış enerji tüketimini artırmaktadır. Model l'de, düşük enerji tüketimi seviyelerinde finansal gelişmenin etkisi daha düşükken, 
orta ve yüksek enerji tüketimi olan ülkelerde Bankacllık sektörünün etkisi daha yüksektir. Model 2'de, tahvil sektörü, düşük enerji tüketimi olan ülkelerde yüksek etkiye sahiptir ancak anlamsizdır. Orta ve yüksek enerji tüketimi seviyelerinde olumlu ve anlaml bir etkiye sahiptir. Bankacıllk sektörünün enerji tüketimi üzerindeki etkisi, borç sektöründen üç kat daha fazladır. Ayrıca, bankacıllk sektörünün düşük enerji tüketimi kantili üzerinde önemli bir etkisi vardır. Politika yapıclların Ekonomik Büyüme Sürecinde finansal gelişme rolünü kullanmalarl için başka bir sonuç bulunmuştur.

Anahtar Kelimeler: Enerji Tüketimi, Finansal Gelişme, Ekonomik Büyüme, Panel Kantil Regresyonu, G-7 Ülkeleri.

\section{Introduction}

Kraft \& Kraft's (1978) literature pioneering study enabled energy to be used as the main argument in economic growth (EG hereafter) and economic development (ED hereafter) studies. The EG-Energy consumption (EC hereafter) link is one of the most focused topics in the literature for many years (Soytas \& Sarı, 2003; Lee \& Chang, 2008; Narayan \& Smyth, 2008; Apergis \& Payne, 2009; Ozturk et al., 2010; Ozturk, 2010; Payne, 2010). However, the nexus between financial development (FD hereafter) - EC is one of the topics that have been intensifying by researchers only for the last 10 years (Karanfil, 2009; Sadorsky, 2010).

The world economy is supposed to improve at an average annual rate of $3.4 \%$ over the period 2014 to 2040. On the other hand, economic expectations play a critical role not only in the GDP growth rate but also in determining EC, which determines how growth will be distributed across different sectors. For the world as a whole, it can be said that GDP growth further increases EC. However, this nexus has significantly differentiated between countries in recent years. For example among the group of OECD economies, GDP growth has been associated with a slight decrease in primary energy need between 2000 to 2014. Otherwhere, the relationships between EC and EG remain strong (China, Middle East, India, etc). Consequently, for every one percentage point rise in non-OECD EG between 2000 to 2014, energy demand increased by around $0.7 \%$ (World Energy Outlook, 2016).

Regarding the relations between FD and EC, the common view is that if EC level is high, this will leads to FD, leading to more investment activities which needs more financial resources (Shahbaz \& Lean, 2012; Liu et al., 2018, Durusu-Ciftci et al., 2020). FD is known as a curicial factors to determine the energy demand level. Developing countries that continues to improve their stock market will have a rise in energy demand more than an increase in income. In these countries, if FD not inserted in energy demand projection, it will be underestimated reel energy demand (Sadorsky, 2010). Ignoring the FD additional impact on energy demand will result in energy policies falling short of their intended aims. To reach greenhouse gas emission targets may also be more difficult if these targets are formulated regardless of the impact of stock market development on energy demand. According to Sadorsky (2011), FD rises the energy demand in the Central and Eastern European border economies. Long-run FD elasticities are smaller than related long-run price elasticities. In other words, the FD variables do not affect EC as well as energy prices. These variables have a statistically significant and positive effect on EC even after controlling the effect of income and energy prices. These results also have an impact on energy demand and greenhouse gas emissions (Sadorsky, 2011). There is a large literature that investigates the relationship between EG and FD, but FD effects 
on the energy demand have received little attention (Sadorsky, 2010). Financial development defined broadly increases FDI, increases in banking, and in-stock market activity.

The FD-EC relation can explain in four-channel. If the causality is unidirectional from FD to EC, we can say FD increases EC in three ways, (Sadorsky, 2010, 2011; Zhang, 2011; Aslan et al., 2014). First, the direct effect, second the business effect and the third wealth effect (Sadorsky, 2011). Direct effects means people will buy goods which consumes more energy, business effect means more business more energy consumption and the wealth effect can explain with high economic confidence. But also FD may lead to modern technologies which can decrease energy demand in the second channel by using durable goods which consumes less energy and using production processes which are energy-efficient than the others. This will increase savings also support the financial development (Jalil \& Feridun, 2011; Shahbaz et al., 2013; Mahalik \& Mallick, 2014; Durusu-Ciftci et al., 2020). In the case of the third channel, there is bidirectional causality between EC and FD and in the last channel, some studies found no effect on EC (Coban \& Topcu, 2013; Ozturk \& Acaravci, 2013). The empirical researches assessing financial growth and energy sonsumption are summarized in Table 1.

Table 1: A Review of the Empirical Studies on the FD-EC Nexus

\begin{tabular}{|c|c|c|c|c|}
\hline Wwriters & Methodology & $\begin{array}{l}\text { Time } \\
\text { Range }\end{array}$ & Countries & Finding \\
\hline Sadorsky-2010 & GMM & $\begin{array}{l}1990- \\
2006\end{array}$ & $\begin{array}{l}22 \text { Emerging } \\
\text { Countries }\end{array}$ & $\mathrm{FD} \rightarrow \mathrm{EC}$ \\
\hline Sadorsky-2011 & GMM & $\begin{array}{l}1996- \\
2006\end{array}$ & $\begin{array}{l}\text { Selected } 9 \\
\text { European } \\
\text { Countries }\end{array}$ & $\mathrm{FD} \rightarrow \mathrm{EC}$ \\
\hline $\begin{array}{l}\text { Shahbaz \& } \\
\text { Lean-2012 }\end{array}$ & $\begin{array}{l}\text { ARDL- } \\
\text { VECM }\end{array}$ & $\begin{array}{l}1971- \\
2008\end{array}$ & Tunisia & $\mathrm{FD} \leftrightarrow \mathrm{EC}$ \\
\hline $\begin{array}{l}\text { Çoban \& } \\
\text { Topcu-2013 }\end{array}$ & GMM & $\begin{array}{c}1990- \\
2011\end{array}$ & EU-27 & $\begin{array}{c}\mathrm{FD} \stackrel{\leftrightarrow}{\rightarrow} \mathrm{EC} \text { (No impact for EU-27) } \\
\mathrm{FD} \rightarrow \mathrm{EC} \text { (Old member countries) } \\
\mathrm{BD} \rightarrow \mathrm{EC} \text { (inverted U-shaped for New } \\
\text { members) }\end{array}$ \\
\hline Islam et al. 2013 & $\begin{array}{l}\text { ARDL- } \\
\text { VECM }\end{array}$ & $\begin{array}{l}1971- \\
2009\end{array}$ & Malaysia & $\begin{array}{l}\mathrm{FD} \leftrightarrow \mathrm{EC}(\mathrm{L}-\text { run }) \\
\mathrm{EC} \rightarrow \mathrm{FD}(\text { S-run })\end{array}$ \\
\hline Aslan et al. 2014 & Panel Data & $\begin{array}{l}1980- \\
2011\end{array}$ & $\begin{array}{c}\text { Middle } \\
\text { Eastern } \\
\text { countries }\end{array}$ & $\begin{array}{l}\mathrm{EC} \leftrightarrow \mathrm{BD}(\text { L-run }) \\
\mathrm{BD} \rightarrow \mathrm{EC}(\text { St-run })\end{array}$ \\
\hline Tang \& Tan 2014 & $\begin{array}{c}\text { Time series } \\
\text { analysis }\end{array}$ & $\begin{array}{l}1972- \\
2009\end{array}$ & Malaysia & $\mathrm{EC} \leftrightarrow \mathrm{FD}$ \\
\hline Chang-2015 & $\begin{array}{l}\text { Panel } \\
\text { threshold } \\
\text { regression }\end{array}$ & $\begin{array}{l}1999- \\
2008\end{array}$ & 53 countries & $\mathrm{FD} \rightarrow \mathrm{EC}$ \\
\hline Furuoka-2015 & Panel Data & $\begin{array}{c}1980- \\
2012\end{array}$ & $\begin{array}{c}\text { Asian } \\
\text { countries }\end{array}$ & $\mathrm{EC} \rightarrow \mathrm{FD}$ \\
\hline
\end{tabular}


Table 1 continue

\begin{tabular}{|c|c|c|c|c|}
\hline $\begin{array}{l}\text { Topcu \&Payne } \\
2017\end{array}$ & Panel Data & $\begin{array}{l}1990- \\
2014\end{array}$ & $\begin{array}{l}32 \text { high- } \\
\text { income } \\
\text { countries }\end{array}$ & $\begin{array}{c}\mathrm{SMI}(\uparrow) \rightarrow \mathrm{EC}(\downarrow) \\
\text { FD } \stackrel{\leftrightarrow}{\rightarrow} \mathrm{EC}(\text { No impact) }\end{array}$ \\
\hline Destek-2018 & Panel Data & $\begin{array}{l}1991- \\
2015\end{array}$ & $\begin{array}{c}17 \text { Emerging } \\
\text { Economies }\end{array}$ & $\mathrm{FD} \rightarrow \mathrm{EC}(\downarrow)$ \\
\hline Yue et al. 2019 & PSTR model & $\begin{array}{l}2006- \\
2015\end{array}$ & $\begin{array}{l}21 \text { transitional } \\
\text { countries }\end{array}$ & $\mathrm{FD} \rightarrow \mathrm{EC}$ \\
\hline Gaies et al. 2019 & $\begin{array}{c}\text { Dynamic } \\
\text { panel GMM }\end{array}$ & $\begin{array}{l}1996- \\
2014\end{array}$ & $\begin{array}{c}\text { MENA } \\
\text { countries }\end{array}$ & $\mathrm{FD} \rightarrow \mathrm{EC}$ inverted U shaped \\
\hline Ciftci et al. 2020 & $\begin{array}{c}\text { Panel } \\
\text { Granger } \\
\text { Causality }\end{array}$ & $\begin{array}{l}1971- \\
2014\end{array}$ & $\begin{array}{l}21 \text { Emerging } \\
\text { Economies }\end{array}$ & $\begin{array}{c}\text { FD } \rightarrow \text { EC (Chile, India and Pakistan) } \\
\text { EC } \leftrightarrow \text { FD (South Korea and South } \\
\text { Africa) } \\
\begin{array}{c}\text { FD } \leftrightarrow \text { EC (No impact for } 13 \text { other } \\
\text { markets) }\end{array}\end{array}$ \\
\hline $\begin{array}{l}\text { Anton \& Nucu, } \\
2020\end{array}$ & Panel Data & $\begin{array}{l}1990- \\
2015\end{array}$ & $\begin{array}{c}\text { EU-28 } \\
\text { Countries }\end{array}$ & $\mathrm{FD} \rightarrow \mathrm{REC}$ \\
\hline $\begin{array}{l}\text { Wang \& Gong, } \\
2020\end{array}$ & $\begin{array}{c}\text { Threshold } \\
\text { model }\end{array}$ & $\begin{array}{l}1997- \\
2017\end{array}$ & $\begin{array}{l}30 \text { China } \\
\text { provinces }\end{array}$ & $\mathrm{FD} \rightarrow \mathrm{EC}$ \\
\hline
\end{tabular}

FD: Financial development, EC: Energy consumption, BD: Banking Developing Index, SMI: Stock Market Index, REC: Renewable Energy Consumption.

Differentiation of empirical findings on the FD-EC nexus can be based on using the different country samples, different econometric models, and also different period data. We try to fill this gap, to fill this gap though less in literature, this paper focused on examining the impact of FD, FDI, GDP and energy prices on EC for G-7 countries covered the 1980-2018 data period. In order to analyze the effect of FD, two models were established using the bond market development index and bank sector development index. In this case, for the first time, the panel quantile regression model is used since the units in the country category are, to a large degree, heterogeneous in terms of energy consumption. If the results show that FD affects EC through two different channels and at different levels, this relationship also affects the energy policy maker's strategies.

This paper is organized as follows: Section 2 presents the econometric methods and empirical results and section 3 reported the concluding remarks with a policy recommendation. Research and publication ethics were complied with in this study, which did not require ethics committee approval or any other permission. 


\section{Econometric Methods and Empirical Results}

\subsection{Data Set}

The annual data of 1980-2018 are examined to investigate the relationship between FD -EC using two different indices for FD in advanced G-7 countries ${ }^{1}$. The empirical model has assigned as a reduced form dynamic panel model of ED following Sadorsky (2010).

Table 2: Variable Description and Sources

\begin{tabular}{|c|c|c|c|}
\hline Name & Variable & Definition & Source \\
\hline Economic Growth & GDP & Per capita (constant 2010 US\$) & WDI \\
\hline Energy Consumption & $\mathrm{EC}$ & $\begin{array}{l}\mathrm{kg} \text { of oil equivalent per capita- constant } 2010 \text { US } \\
\text { dollars }\end{array}$ & WDI \\
\hline Real Oil Prices & EP & 2010 constant US dollars (per barrel) & BPSR \\
\hline Foreign Direct Investment & FDI & Net inflows (\% of GDP) & WDI \\
\hline \multirow{4}{*}{$\begin{array}{l}\text { Banking Sector } \\
\text { Development Index } \\
\left(\text { BankD }_{\text {index }}\right)\end{array}$} & dbagdp & Deposit money bank assets (\% of GDP) & WB-FDSD \\
\hline & fdgdp & Financial system deposits (\% of GDP) & WB-FDSD \\
\hline & llgdp & Liquid liabilities (\% of GDP) & WB-FDSD \\
\hline & pcrdbgdp & $\begin{array}{l}\text { Private credit by deposit money banks } \\
\text { (\% of GDP) }\end{array}$ & WB-FDSD \\
\hline \multirow{3}{*}{$\begin{array}{l}\text { Bond Market } \\
\text { Development Index } \\
\left(\text { BondD }_{\text {index }}\right)\end{array}$} & prbond & Private bond market capitalization ( $\%$ of GDP) & WB-FDSD \\
\hline & pubond & Public bond market capitalization (\% of GDP) & WB-FDSD \\
\hline & intldebt & International debt issues (\% of GDP) & WB-FDSD \\
\hline
\end{tabular}

WB-WDI: https://datacatalog.worldbank.org/dataset/world-development-indicators

BPSR: British Petroleum Statistical Review. (2019). http://www.bp.com/statisticalreview

WB-FDSD: World Bank Financial Development and Structure Dataset (Revised: September 2019) https://www. worldbank.org/en/publication/gfdr/data/financial-structure-database

\subsection{Methodology}

The panel quantile regression models are used to explain EC measured by the energy use as a function of GDP, FDI net inflows, Real Oil Prices, BankD ${ }_{\text {index }}$ and BondD $_{\text {index }}$ in a panel quantile specification. Following from Sadorsky (2010), the main framework modified for EC is two basic productions function accounting framework yields:

$$
\begin{aligned}
& \text { Model 1: } E C=f\left(G D P, \text { FDI, } E P, B_{\text {BankD }}\right. \text { index } \\
& \text { Model 2: } E C=f\left(G D P, F D I, E P, B_{\text {index }}\right)
\end{aligned}
$$

Two equations are used to explain the relationship between EC and FD. This model allows us to examine the factors that drive TFEE at various quantitative stages. In areas of FDEC, data also have a sharp peak or thick tail. Compared to the ordinary least squares method, quantile regression does not require strong estimates for error terms, in this case, the quantile

1 Canada, France, Germany, Italy, Japan, United Kingdom, and the United States. 
regression can supply more robust estimation results (Koenker \& Bassett, 1978). Quantile regression can be more detailed in explaining the conditional distribution of the variables explained, rather than merely evaluating the conditional expectations of the variables explained. Regression coefficient estimators often vary between quantiles, i.e. the results of explanatory variables on the variables are different between quantiles (Yan et al., 2019).

OLS regression is the minimum variance unbiased estimator. First, if the random disturbance term of the OLS regression is zero mean and is identically distributed (i.i.d.). Second, if the error term is a normal distribution. Nonetheless, De Silva et al., (2016) stated that these assumptions are not true in real economic life since the data of socioeconomic indicators may have different distributional patterns. The quantile regression estimation technique established by Koenker \& Bassett Jr., (1978), is a widely used method to overcome the limitations of the ordinary least-square (OLS) approach.

The study uses annual statistics for G-7 countries covering the period between 1980 and 2018. On the availability of data, countries and time periods are chosen appropriately. To find the relationship between FD and EC, all data except the EC were used as a proxy variable. The data is obtained from WDI databases, British Petroleum Statistical Review, and World Bank Financial Development and Structure Dataset (Revised: September 2019), while all variables are expressed in logarithmic.

\subsection{Empirical Findings}

The starting point of the research is to investigate the unit root stationary of variables. Table 3 displays the stationary of 6 variables in the first difference using the unit root analysis approach developed by Im-Pesaran-Shın (2003) (IPS). After determining the stationary in all variables, the second stage of the application can be started.

Table 3: Panel Unit Root Test.

\begin{tabular}{lcccc}
\hline & W-Trend & N- Trend & W-Trend & N-Trend \\
\hline Variables & \multicolumn{2}{c}{ Level } & \multicolumn{2}{c}{ 1. DF } \\
\hline BankD $_{\text {index }}$ & 0.94193 & -0.37503 & $-5.18520^{* * * *}$ & $-6.40582^{* * *}$ \\
\hline BondD $_{\text {index }}$ & 5.06971 & -0.72699 & $-17.0023^{* * *}$ & $-18.7638^{* * *}$ \\
\hline EP & -0.36757 & -0.99692 & $-11.4990^{* * *}$ & $-12.3532^{* * *}$ \\
\hline EC & 5.09706 & 2.22320 & $-14.7334^{* * *}$ & $-10.6502^{* * *}$ \\
\hline FDI & 0.57730 & -0.47727 & $-18.7507^{* * *}$ & $-19.6194^{* * *}$ \\
\hline GDP & 2.78453 & -1.01364 & $-5.78793^{* * *}$ & $-5.16892^{* * *}$ \\
\hline
\end{tabular}

*** denotes $1 \%$ statistically significance levels.

The panel unit root analyses of all variables for six groups were evaluated in both the levels and the first differences in Table 3 . Table 3 shows that while the variables are evaluated in levels, the unit root hypothesis cannot be dismissed. However, when the first differences are used, the hypothesis of unit root non-stationary is rejected at the $1 \%$ level of significance. Table 3 displays the outcomes of the test and supports all panel variables stationary at the first difference level across. 
Table 4: Panel Quantile Estimates for Model 1 (dependent variable= EC)

\begin{tabular}{|c|c|c|c|c|c|c|c|c|c|}
\hline \multirow[b]{2}{*}{ Variables } & \multicolumn{9}{|c|}{ Quantiles } \\
\hline & $10 \%$ & $20 \%$ & $30 \%$ & $40 \%$ & $50 \%$ & $60 \%$ & $70 \%$ & $80 \%$ & $90 \%$ \\
\hline GDP & $-0.0024^{* * *}$ & -0.0006 & $-0.0022^{* * *}$ & $-0.0023^{* * *}$ & $-0.0025^{* * *}$ & ${ }^{*}-0.0024^{* * * *}$ & $-0.0025^{* * *}$ & $-0.0024^{* * *}$ & $-0.0024^{* * *}$ \\
\hline EP & $0.0057^{* * * *}$ & 0.0003 & $0.0048^{* * * *}$ & $0.0050^{* * * *}$ & $0.0056^{* * *}$ & $0.0053^{\text {**** }}$ & $0.0055^{* * *}$ & $0.0055^{* * *}$ & $0.0054^{* * *}$ \\
\hline FDI & $0.0016^{* * *}$ & $0.0024^{* * * *}$ & $0.0024^{* * *}$ & $0.0024^{* * *}$ & $0.0023^{* * *}$ & $0.0025^{* * *}$ & $0.0025^{* * *}$ & $0.0025^{* * *}$ & $0.0025^{* * *}$ \\
\hline BankD $_{\text {index }}$ & $1.66^{* * * *}$ & -3.97 & $1.00^{* * * *}$ & $6.85^{* * * *}$ & $9.21^{* * * *}$ & $7.76^{* * * *}$ & $7.98^{* * * *}$ & $9.01^{\text {**** }}$ & $8.44^{* * * *}$ \\
\hline
\end{tabular}

To get more insight into the relationship between EC and FD, two indexes were used as the FD indicator and Panel quantile estimates analysis was performed. In Equation 1, the effect of GDP, EP, FDI, and BankDindex variables on the dependent variable EC was estimated by using quantiles from $\% 10$ to \%90. Also in Equation 2, the effect of GDP, EP, FDI, and BondD $\mathrm{D}_{\text {index }}$ variables on the dependent variable $\mathrm{EC}$ was estimated by using quantiles from $\% 10$ to \%90. The estimates from Equation 1-2 are stated by Tables 4-5 and for the full sample per quantile (i.e., low-energy consumption-10-30\%; medium-energy consumption-30-70\%; and high-energy consumption-70-90\%).

Most of the results obtained from the estimates by using the EC variable have been confirmed. According to the changes observed in the shares of 10-90\% groups, if we take into the GDP variable first, an increase in GDP for G-7 countries decreases energy consumption in all quantiles. While this effect is insignificant at only a $20 \%$ level, it has a reducing effect close to each other in other quantiles. In other words, economic growth in G-7 countries decreases EC.

Conversely, an increase in EP increases the EC, also this positive effect is similar and significant in all quantiles except $\% 20$. Moreover, in all quantiles, the FDI variable provided important and close results. In accordance with this effect, a 1\% increase in FDI will cause an average increase of $0.24 \%$ in EC.

The first index of financial development, $\mathrm{BankD}_{\text {index }}$ is significant and positive in all quantiles except $\% 20$, in other words, an increase in $\mathrm{BankD}_{\text {index }}$ increases the EC.

Table 5: Panel Quantile Estimates for Model 2 (dependent variable= EC)

\begin{tabular}{|c|c|c|c|c|c|c|c|c|c|}
\hline \multirow[b]{2}{*}{ Variables } & \multicolumn{9}{|c|}{ Quantiles } \\
\hline & $10 \%$ & $20 \%$ & $30 \%$ & $40 \%$ & $50 \%$ & $60 \%$ & $70 \%$ & $80 \%$ & $90 \%$ \\
\hline GDP & 0.0004 & -0.0010 & 0.0095 & $-0.0021^{* * *}$ & $-0.0031^{* * *}$ & $-0.0028^{* * * *}$ & $-0.0032^{* * *}$ & $-0.0029^{* * * *}$ & $-0.0027^{* * * *}$ \\
\hline EP & -0.0021 & 0.0017 & -0.0272 & $0.0048^{* * * *}$ & $0.0079^{* * * *}$ & $0.0067^{* * * *}$ & $0.0082^{* * * *}$ & $0.0071^{* * * * *}$ & $0.0065^{* * *}$ \\
\hline FDI & $0.0021^{* * * *}$ & $0.0010^{* * * *}$ & $0.0010^{* * * *}$ & $0.0011^{* * *}$ & $0.0020^{* * * *}$ & $0.0021^{* * *}$ & $0.0018^{* * *}$ & $0.0025^{* * *}$ & $0.0020^{* * *}$ \\
\hline Bond ${ }_{\text {Dinde }} \mathrm{X}$ & 4.43 & 2.51 & 1.13 & 6.24 & $2.71^{* * * *}$ & $1.97^{* * * *}$ & $3.32^{* * * *}$ & $2.43^{* * * *}$ & $1.95^{* * * *}$ \\
\hline
\end{tabular}

**** denote $1 \%$ statistically significance levels. 
According to Table 5 which compiled from equation 2, it is seen that GDP has a positive effect on EC only at $10 \%$ and $30 \%$ quantiles, but this effect is meaningless. Also, compatible with the first analysis, there is a meaningly and negative effect on all other quantiles.

The EP variable affects EC strongly and positively in the level of 40-90\% and also this effect of EP is higher than the first analysis. The effects of FDI on all quantiles are also important and optimistic.

BondD $_{\text {index }}$ is positive in all quantiles, but the relationship is meaningless up to $50 \%$. While EC increases in the level of $60 \%$ to $90 \%$, the FD variable has an increasing and then decreasing effect. The effect of BondD $\mathrm{B}_{\text {index }}$ is higher than all other variables, but the average effect of the BankDindex variable on $\mathrm{EC}$ is 3 times more than the effect of the BondD $\mathrm{Dndex}_{\text {ind }}$ variable.

\section{Conclusion}

This paper focused on examining the effect of FD, FDI, GDP and energy prices on EC for G-7 countries covered the 1980-2018 data period. While analyzing, financial development is calculated over the bond and bank sector development index. In this case, the panel quantile regression model is first applied since in terms of energy consumption the units within the country group are in large measure heterogeneous.

According to the panel analysis findings, bank market development, and bond market development indices, which are used as financial development data, have a positive influence on EC. Moreover the first of the other variables included in the analysis, an increase in GDP decreases EC in all quantiles. In other words, EG in G-7 countries decreases EC. It can be explained with modern technologies that can decrease energy demand by the usage of less energy-intensive, durable goods and the use of energy-efficient technologies in manufacturing processes. Secondly, an increase in EP increases the EC, also this positive effect is similar and significant in all quantiles except $\% 20$. We can say that energy demand is inelastic. Thirdly in accordance with the FDI variable effect, a $1 \%$ increase in FDI will cause an average increase of $0.24 \%$ in EC.

According to equation 2, it is seen that GDP has a positive effect on EC only at 10\% and $30 \%$ quantiles, but this effect is insignificant. However, compatible with the first analysis, there is a significant and negative effect in all other quantiles. The EP variable has a significant and positive effect on EC in the level of 40-90\% and also this effect of EP is higher than the first analysis. As well FDI has a significant and positive effect on all quantiles. BondD $\mathrm{D}_{\text {index }}$ is positive in all quantiles, but the relationship is not significant up to $50 \%$. While EC increases in the range of $60 \%$ to $90 \%$, the FD variable has an increasing and then decreasing effect. The effect of $\mathrm{BondD}_{\text {index }}$ is higher than all other variables, but the average effect of the $\mathrm{BankD}_{\text {index }}$ index on $\mathrm{EC}$ is 3 times more than the effect of the $\mathrm{BondD}_{\text {index }}$ index.

When the results of the energy literature studies are analyzed, the causal route between energy use and financial growth cannot be predicted with certainty. However, this causality is known to be of considerable significance to the effective planning and management of energy policy. 


\section{References}

Apergis, N. \& Payne, J. E. (2009). Energy consumption and economic growth in Central America: Evidence from a panel cointegration and error correction model. Energy Economics, 31(2), 211216.

Aslan, A., Apergis, N. \& M. Topcu. (2014). Banking development and energy consumption: Evidence from a panel of Middle Eastern countries. Energy 72: 427-33.

Bera, A. K., Galvao, A. F., Montes-Rojas, G. V. \& Park, S. Y. (2016). Asymmetric laplace regression: Maximum likelihood, maximum entropy and quantile regression. Journal of Econometric Methods, 5(1), 79-101.

BPSR: British Petroleum Statistical Review. (2019). http://www.bp.com/statisticalreview.

Čihák, M., Demirgüç-Kunt, A., Feyen, E. \& Levine, R. (2012). Benchmarking financial development around the world. World Bank Policy Research Working Paper, 6175, 1-54.

Çoban, S. \& M. Topcu. (2013). The nexus between financial development and energy consumption in the EU: A dynamic panel data analysis. Energy Economics, 39: 81-88.

De Silva, P. N. K., Simons, S. J. R. \& Stevens, P. (2016). Economic impact analysis of natural gas development and the policy implications. Energy Policy, 88, 639-651.

Denisova, V. (2020). Financial Development and Energy Consumption: Evidence from Germany. International Journal of Energy Economics and Policy, 10(2), 35-39.

Destek, M. A. (2018). Financial development and energy consumption nexus in emerging economies. Energy Sources, Part B: Economics, Planning, and Policy, 13(1), 76-81.

Gómez, M. \& Rodríguez, J. C. (2019). Energy consumption and financial development in NAFTA countries, 1971-2015. Applied Sciences, 9(2), 302.

Im, K. S., Pesaran, M. H. \& Shin, Y. (2003). Testing for unit roots in heterogeneous panels. Journal of Econometrics, 115(1), 53-74.

Islam, F., M. Shahbaz, Ahmed, A. U. \& Alam, M. M. (2013). Financial development and energy consumption nexus in Malaysia: A multivariate time series analysis. Economic Modelling, 30: $435-41$.

Jalil, A. \& Feridun,M. (2011). The impact of growth, energy and financial development on the environment in China: A cointegration analysis. Energy Economics, 33(2), 284-291.

Karanfil, F. (2009). How many times again will we examine the energy-income nexus using a limited range of traditional econometric tools?. Energy Policy, 37(4), 1191-1194.

Koenker, R. (2004). Quantile regression for longitudinal data. Journal of Multivariate Analysis, 91(1), 74-89.

Koenker, R. \& Bassett Jr, G. (1978). Regression quantiles. Econometrica: Journal of the Econometric Society, 33-50.

Kraft, J. \& Kraft, A. (1978). On the relationship between energy and GNP. The Journal of Energy and Development, 401-403.

Lee, C. C. \& Chang, C. P. (2008). Energy consumption and economic growth in Asian economies: A more comprehensive analysis using panel data. Resource and Energy Economics, 30(1), 50-65.

Liu, L., Zhou, C., Huang, J. \& Hao, Y. (2018). The impact of financial development on energy demand: Evidence from China. Emerging Markets Finance and Trade, 54(2), 269-287.

Mahalik, M. K. \& Mallick, H. (2014). Energy consumption, economic growth and financial development: Exploring the empirical linkages for India. The Journal of Developing Areas, 139-159.

Narayan, P. K. \& Smyth, R. (2008). Energy consumption and real GDP in G7 countries: New evidence from panel cointegration with structural breaks. Energy Economics, 30(5), 2331-2341. 
Ozturk, I. (2010). A literature survey on energy-growth nexus. Energy Policy, 38(1), 340-349.

Ozturk, I. \& Acaravci, A. (2013). The long-run and causal analysis of energy, growth, openness and financial development on carbon emissions in Turkey. Energy Economics, 36, 262-267.

Ozturk, I., Aslan, A. \& Kalyoncu, H. (2010). Energy consumption and economic growth relationship: Evidence from panel data for low and middle income countries. Energy Policy, 38(8), 4422-4428.

Payne, J. E. (2010). Survey of the international evidence on the causal relationship between energy consumption and growth. Journal of Economic Studies.

Sadorsky, P. (2010). The impact of financial development on energy consumption in emerging economies. Energy Policy 38(5): 2528-35.

Sadorsky, P. (2011). Financial development and energy consumption in Central and Eastern European frontier economies. Energy Policy 39(2): 999-1006.

Shahbaz, M. \& Lean, H. H. (2012). Does financial development increase energy consumption? The role of industrialization and urbanization in Tunisia. Energy Policy, 40, 473-479.

Shahbaz, M.,Hye, Q. M. A., Tiwari, A. K. \& Leitão, N.C. (2013).Economic growth, energy consumption, financial development, international trade and $\mathrm{CO} 2$ emissions in Indonesia. Renewable and Sustainable Energy Reviews, 25, 109-121.

Shahbaz, M., Khan, S. \& Tahir, M. I. (2013). The dynamic links between energy consumption, economic growth, financial development and trade in China: Fresh evidence from multivariate framework analysis. Energy Economics, 40, 8-21.

Sherwood, B. \& Wang, L. (2016). Partially linear additive quantile regression in ultra-high dimension. The Annals of Statistics, 44(1), 288-317.

Soytas, U. \& Sari, R. (2003). Energy consumption and GDP: Causality relationship in G-7 countries and emerging markets. Energy Economics, 25(1), 33-37.

Tang, C. F. \& B. W. Tan. (2014). The linkages among energy consumption, economic growth, relative price, foreign direct investment, and financial development in Malaysia. Quality \& Quantity 48(2): 781-97.

Topcu, M. \& J. E. Payne. (2017). The financial development-energy consumption nexus revisited. Energy Sources, Part B: Economics, Planning, and Policy 12(9): 822-30.

Wang, Y. \& Gong, X. (2020). Does financial development have a non-linear impact on energy consumption? Evidence from 30 provinces in China. Energy Economics, 90, 104845.

WB-FDSD : World Bank Financial Development and Structure Dataset (Revised: September 2019) https://www.worldbank.org/en/publication/gfdr/data/financial-structure-database.

WDI: World Development Indicators. https://datacatalog.worldbank.org/dataset/world-developmentindicators.

Yan, D., Kong, Y., Ren, X., Shi, Y. \& Chiang, S. (2019). The determinants of urban sustainability in Chinese resource-based cities: A panel quantile regression approach. Science of the total environment, 686, 1210-1219.

Zhang, Y. J. (2011). The impact of financial development on carbon emissions: An empirical analysis in China. Energy policy, 39(4), 2197-2203.

Zhu, H., Duan, L., Guo, Y. \& Yu, K. (2016a). The effects of FDI, economic growth and energy consumption on carbon emissions in ASEAN-5: Evidence from panel quantile regression. Economic Modelling, 58, 237-248.

Zhu, H., Guo, Y., You, W. \& Xu, Y. (2016b). The heterogeneity dependence between crude oil price changes and industry stock market returns in China: Evidence from a quantile regression approach. Energy Economics, 55, 30-41. 